\title{
Regional Assessment of the Food Security Situation in West Africa with GIS
}

\author{
E. C. Merem ${ }^{1, *}$, Y. Twumasi ${ }^{2}$, J. Wesley ${ }^{1}$, M. Alsarari ${ }^{1}$, S. Fageir ${ }^{1}$, M. Crisler ${ }^{1}$, C. Romorno ${ }^{1}$, \\ D. Olagbegi ${ }^{1}$, A. Hines ${ }^{3}$, G. S. Ochai ${ }^{4}$, E. Nwagboso ${ }^{5}$, S. Leggett ${ }^{6}$, D. Forster ${ }^{1}$, V. Purry ${ }^{1}$, J. Williams ${ }^{1}$ \\ ${ }^{1}$ Department of Urban and Regional Planning, Jackson State University, Jackson, MS, USA \\ ${ }^{2}$ Department of Urban Forestry and Natural Resources, Southern University, Baton Rouge, LA, USA \\ ${ }^{3}$ Department of Public Policy and Administration, Jackson State University, Jackson, MS, USA \\ ${ }^{4}$ African Development Bank, AfDB, Avenue Joseph Anoma, Abidjan, Ivory Coast \\ ${ }^{5}$ Department of Political Science, Jackson State University, Jackson, MS, USA \\ ${ }^{6}$ Department of Behavioral and Environmental Health, Jackson State University, Jackson, MS, USA
}

\begin{abstract}
The continent of Africa has tremendous potential in agriculture with more than half of the world's fertile unused land therein. In the case of West Africa known for its abundance of natural and human resources, farming not only represents approximately over a third of the region's wealth and more than half of the work force, but the sector is a major catalyst to attaining food security and rapid economic growth. Yet in the past decades, the gloomy performance in food production remains compounded by the dependence on food imports combined with the threats of famine and declining productivity. Even though food security attainment ranks as a major challenge, food production has increased in the recent past but with little success due to unmet goals in the set targets and the socio-economic and physical constraints in the larger agricultural structure. At the same time, there exists limited use of mix scale tools of GIS and descriptive statistics in gauging food security and agricultural activities in West Africa. Without it, managers face the grueling task of making the right decisions in critical areas requiring intervention to ensure food security. For that, this paper will fill that void by analyzing the food security situation in West Africa. Emphasis is on the issues, trends, production activities, factors and efforts. With the results showing changes in farm variables made up of various food types, agricultural land and other essential elements in food production coupled with gradual declines in some nations, GIS mapping points to a gradual spreading of food security indicators with firm concentration across different countries. Just as changes in production associated with food security originate from socio-economic and physical elements, the paper offered various solutions ranging from the need for education and monitoring to the design of regional food information system, efficient policy, storage facilities, precision farming and more use of GIS.
\end{abstract}

Keywords Region, Food security, GIS, West Africa, Agriculture, Nations and Factors

\section{Introduction}

The continent of Africa has great agricultural potentials with over $50 \%$ of the globe's untilled arable landscape therein [1], coupled with a thriving agriculture and agribusiness sector worth $\$ 313$ billion in 2010 and projected to be $\$ 1$ trillion by 2030 [2]. In the case of West Africa, known for its abundance of natural and human resources [3], farming not only represents approximately over a third of the region's wealth and more than half of the work force [4], but the sector is essential to attaining food

* Corresponding author:

edmund.c.merem@jsums.edu (E. C. Merem)

Published online at http://journal.sapub.org/fph

Copyright $@ 2019$ The Author(s). Published by Scientific \& Academic Publishing This work is licensed under the Creative Commons Attribution International

License (CC BY). http://creativecommons.org/licenses/by/4.0/ security and rapid economic growth [5]. Being a region where food is a necessity of life, its importance at the household level serves the needs of citizens as basic means of sustenance [6]. Considering its essence [7, 1], food abundance makes a nation partly secured, especially when issues of social security are at the forefront. Nevertheless, the livelihoods of people can come under threat whenever that privilege is absent [8]. Because the concern for food security in an economy rests on the role of human element in economic development, at the national level, food availability and its lack of, can influence peace and stability [9]. Conceptually, sustainable food security implies access by all to enough food for a healthy life at present, plus the ability to ensure abundance for posterity [10]. From the collective concerns at the time, food security was brought to lime light in 1974 at a world food conference when governments saw the need to strategize on how best to improve farm outputs to match the needs of citizens 
$[11,12]$. Food security can be said to exist when "all people, at all times, have physical and economic access to sufficient, safe and nutritious food to meet their dietary needs and food preferences for an active and healthy life" as manifested in a handful of nations in the West African zone in 2014 [14-18].

The four major scopes of food security consist of availability, accessibility, adequate use, and the stability of market supplies always [19-27]. In a region where food security is better understood in terms of agricultural output on land [28-31] because farming maintains an intricate dominance in the region's economy. Local food production and animal husbandry as key elements in the daily food needs of West Africans, provide jobs and revenues for the rural poor. With $60 \%$ of the populace working in agriculture, West African nations still rely heavily on food imports, which tripled over the past 10 years [1]. Given its vast underutilized and abundant arable land, the West African region boasts of diverse agricultural ecosystem rich in farm products of varying types serving local and foreign markets [3]. The region's potentials in the past looked so promising that agriculture accounted for the bulk of foreign payments that accrued these nations [32, 33], even though Nigeria still accounts for $47-60 \%$ of all farm outputs in the zone $[34,5]$. Additionally, a combination of Africa's food crisis of 2007-2008, rising international food prices, low crop yields and a heavy reliance on food imports has left West African governments unable to affordably feed all their citizens [1]. While the food crisis reinvigorated each government's focus on agricultural programs [35-39]; policies to promote regional trade integration have been overlooked [1]. To meet the near-term food consumption needs, governments in the region adopted national agricultural policies that include import bans on rice, maize, cassava and other staples, which account for most of the calories consumed in West Africa [1, 40]. An increase in the potential output of the currently very low production yields of cereals in West Africa, could alter the balance of cereal trade in the region [40]. The analysis of areas of abundant growth for food staples and those with low productivity showed that an open market that connects food demands in growing urban centers and food scarce rural areas to localities with excess crops will enable farmers expand their markets while bringing food into areas with inadequate supplies [1].

Aside from all these, in the past decades, the gloomy profile in the food sector remains compounded by reliance on food imports, threats of famine and declining productivity in farming, undernourishment in certain nations and forced migration [5, 2, 41-44]. Though food production has increased in the recent past, the region did fulfil its first Millennium Development Goal (MDG) of reducing the number of malnourished people by $50 \%$ in $2015[10,45]$. With some of the world's fastest growing populations and the increasing dependence on food imports from the rest of the world to satisfy its consumption needs.
Ensuring food security remains a major challenge in West Africa [46, 11, 32, 47, 48]. Given the reduction of agriculture's input to the GDP, coupled with fiscal stagnation in the region. About $16 \%$ of the population is undernourished. This is more common among women and children, and in the Sahel states and the drier northern areas of coastal countries [49]. The fact that this is now a common problem in West Africa, over the next few years, the sub-region's agriculture sector must brace for a huge increase in food demand as population which stands at about 290 million could exceed 400 million in 2020, and 500 million by 2030 [49]. In addition, there exists limited use of mix scale tools in gauging food security and farm activities in West Africa [50-52]. Aside from the region's progress in handling food crises and presently well-equipped than any other regions in Africa [10, 45]; the situation has become much worse by the role of socio-economic elements (population, urbanization, demand for food, market access, high prices, poor credit facilities, ineffective policy) technology, and the changing environment [53]. Based on meagre coverage of these issues in previous studies, this enquiry will fill that void by evaluating food security situation in the region using a mix-scale model [54-56] with emphasis on the trends, impacts, factors and efforts. The paper has five objectives, the first is to identify the recent issues in food insecurity and production trends, while the second evaluates the threats of food security to the West African region. The third objective covers the assessment of food insecurity impacts. The fourth and fifth objectives are focused on the limiting factors and the design of decision support tools for managers respectively. The study is organized in five sections beginning with the introduction and methods in parts 1 and 2 coupled with the results and discussions in sections 3 and 4 . The concluding portion of the paper is presented in section 5 .

\section{Materials and Methods}

The study area of West Africa consists of 10 nations made up of Benin, Burkina Faso, Chad, Ivory Coast, Ghana, Liberia, Niger, Nigeria, Senegal and Togo (Figure 1). Located along the Lower Coastal Belt and the Sahel North West Zone, the region stretches through a $4,771,810 \mathrm{~km}^{2}$ area from Senegal to Nigeria. In 2018, the study area had a population of over 345 million people [57]; as shown in Table 1. The region has ample potentials in agriculture, but still lags when it comes to regular food access for the populace [5] depending on the season, the geopolitical circumstances of the area in question and conditions of the ecozone [5]. Given the large swath of areas in the zone, the diverse ecology and the pressures from the teeming population and changing climate, the food security situation in some of the places can no longer be dismissed as an issue [14-17]. 


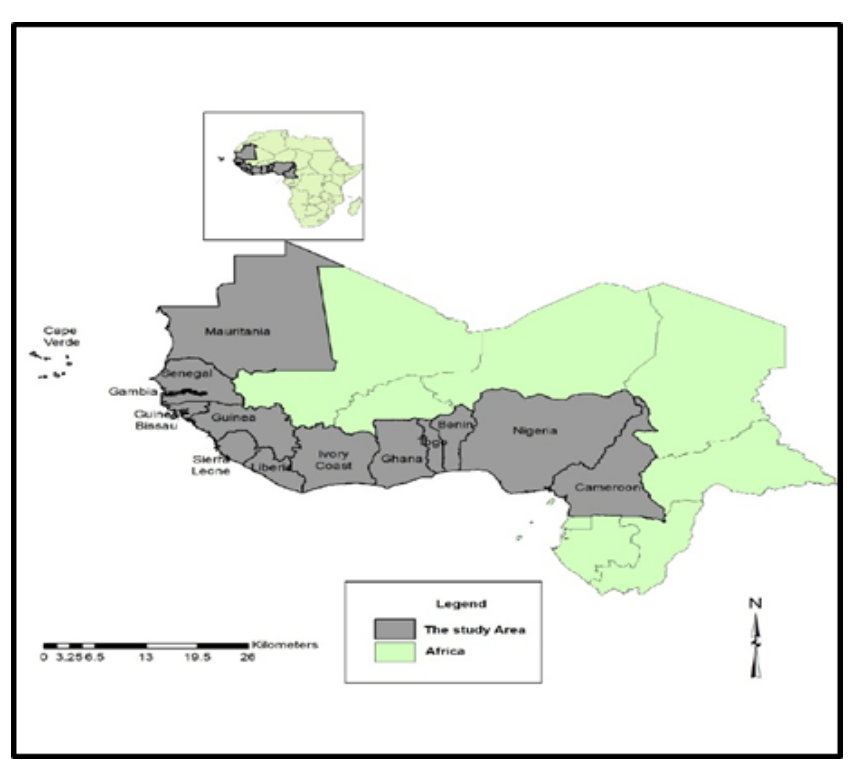

Figure 1. The Study Area, West African Region

Representing approximately $35 \%$ of the region's GDP and $60 \%$ of the active labor force, the agricultural sector remains central to achieving food security and broad-based economic growth therein $[49,2,3]$. Furthermore, agricultural exports generate around US\$6 billion or 3\% of all products and services exported from the sub-region annually.

Table 1. The Population and Size of the Study Area

\begin{tabular}{|c|c|c|c|}
\hline Nations & Populations & Yearly change & Size in $\mathbf{~ m}^{2}$ \\
\hline Benin & $11,367,533$ & $2.77 \%$ & 112,760 \\
\hline Burkina Faso & $19,751,651$ & $2.91 \%$ & 273,600 \\
\hline Chad & $15,353,184$ & $3.04 \%$ & $1,259,200$ \\
\hline Ivory Coast & $24,673,418$ & $2.52 \%$ & 318,000 \\
\hline Ghana & $29,224,653$ & $2.18 \%$ & 227,540 \\
\hline Liberia & $4,807,242$ & $2.57 \%$ & 96,320 \\
\hline Niger & $21,990,737$ & $3.88 \%$ & $1,266,700$ \\
\hline Nigeria & $193,976,255$ & $2.61 \%$ & 910,770 \\
\hline Senegal & $16,125,130$ & $2.80 \%$ & 192,530 \\
\hline Togo & $7,990,926$ & $2.48 \%$ & 54,390 \\
\hline Study Area & $345,260,729$ & NA & $4,711,810$ \\
\hline
\end{tabular}

With substantial part of the globe's productive land in Africa, the study area where only $28 \%$ of arable land was planted in 2005, has vast swaths of cultivable lands as well. Even though potential irrigable land (of 8.9 million hectares) therein consists of less than $10 \%(920,000$ hectares) that is mostly utilized for rice, sugar cane and vegetable production. Most nations of the sub-region, except for Cape Verde and Burkina Faso, have more renewable fresh water than other zones in the world [49]. Added to that, the output potential of West Africa's fishery resources is sizable, but processing facilities are inadequate and huge losses are borne by low lying coastal areas threatened by illegal fishing trawlers [6]. On the upsides, West Africa which reduced by $63 \%$ the proportion of its citizens suffering from hunger saw declines from $24.2 \%$ in $1990-92$ to $9 \%$ in $2014-16$ despite population growth and droughts in the Sahel.

However, such progress is insufficient to reach the World Food Summit (WFS) target of halving the number of people undernourished by 2015. Nevertheless, the sector remains constrained by low productivity and environmental stress. The $25 \%$ decline in rainfall in the region during the last 50 years impacted dryland areas with drops in per hectare yields for most crops considered among the lowest in the world [49]. At same time, the pressures unleashed by limiting factors from climate change [58,59]; to ineffective policy impede the capacity of marginal farm operations and petty traders in generating surplus produce to market to the food sector. In that way, agricultural output is inhibited by under-developed linkages between farmers and markets, limited access to affordable and reliable high-quality seeds and fertilizer, and the lack of information on new farm technologies and best practices. As a result, the region has endured some of the highest transportation costs globally and struggles to enforce regional policies promoting trans-border trade that could have eased food insecurity in needy areas [1].

In the Sahel region of West Africa, where people have suffered from severity of food crises over the past decade and are still recovering from a food crisis back in 2010, drought hazards induced by changing climate is threatening the food security of millions of people $[48,59]$. The crisis has been brought on by unreliable rains that led to poor harvest, particularly in Niger, Chad, Mauritania, Mali, and Burkina Faso. Additionally, the conflict in Northern Mali has not only forced 160,000 people to flee their homes, but the people have fled to neighbouring Niger, Burkina Faso, and Mauritania, with pressure on nations with an already-limited food supply. Elsewhere, the insurgency in North Eastern Nigeria has also created numerous internally displaced persons (IDPs) camps that is compounding an already desperate situation in crisis prone zones dealing with food deficiency and rising prices $[60,61,41,43,44,62]$. Considering the limited use of mix scale tools of GIS and descriptive statistics in gauging food security and agricultural activities in the hot spots of West Africa [63-65]. The lack of access to such information under a mix scale model hinders the decision-making capacity of managers to boost food security in critical areas in need of urgent interventions. Using information from the model will unlock the misery of insecurity and limitations.

\subsection{Method Used}

The paper uses a mix scale approach involving descriptive statistics and secondary data connected to GIS to analyze the growing challenges of food insecurity among nations of the West African region. The spatial information for the enquiry was obtained from several agencies consisting of the NOAA, USGS, World Bank group, the Economic Community of West African States (ECOWAS) and the West African Economic and Monetary Union (WAEMU). Other sources of spatial info emanate from the United States Agency for 
International Development (USAID), the United Nations Food and Agricultural Organization (FAO), the United Nations Office for the Coordination of Humanitarian Affairs (OCHA) and the African Union. In addition to that, the United States Department of Agriculture (USDA), The United Nations High Commission for Refugees (UNHCR) United Nation Development Programme (UNDP), the Organization for Economic Cooperation and Development (OECD) and the African Development Bank (ADB) also provided other information needed in the research. Generally, the bulk of food security indicators relevant to the region and individual nations were obtained from the Nigerian Bureau of Statistics, FAO's FAOSTAT, and the national archives from Ghana, Senegal to Nigeria, The Federal ministry of agriculture and rural development and the USDA Economic Research Service for some of the periods. At the same time, crucial insights on the relevant data also came from the World Agricultural Research Forum, The African Agricultural Research Forum, Network of Farmers and Agricultural Producers Organizations of West Africa and the Alliance for a Green Revolution in Africa (AGRA).

On the one hand, the USDA, the World Bank, FAO Statistics Data Base, USDA Foreign Agricultural Service (FAS), The World Agricultural Outlook Board (WAOB), Oxfam, The Economic Commission for West African States (ECOWAS) and the World Bank provided the secondary data on total production, quantity, export, import, exposure and number of food insecure citizens. On the other, the Government of Nigeria, the United Nations Food and Agricultural Organization (FAO) offered the time series data, monetary information on farm activities on the major crops like cereal and grains highlighting the operations in the region. For additional data needs, the International Fund for Agricultural Development (IFAD) and World Food Program (WFP), The French National Research Agency, the New Partnership for Africa's Development (NEPAD) and Oxfam were critical in the procurement of information on the risks of insecurity, stressed areas, and the econometric data highlighting deficits and changes. In a similar vein, the Consultative Group on International Agricultural Research (CGIAR), Alliance for a Green Revolution in Africa (AGRA), European Union Global Alliance for Resilience in the Sahel and West Africa (AGIR), the Bill and Melinda Gates Foundation and the West African Food Network remained instrumental in the provision of other relevant information. The other key sources encompass the West African Food Industry Economic Operators Network (RESIMAO), the Royal Meteorological Society, Forum on Food Security and Nutrition in Africa, the West and Central African Council for Agricultural Research and Development (CORAF/WECARD). Given that the regional and federal geographic identifier codes of the nations were used to geo-code the info contained in the data sets. This information was processed and analyzed with basic descriptive statistics, and GIS with attention to temporal-spatial trends at the national, state and regional levels in West Africa. The relevant procedures consist of the two stages listed below.

\subsection{Stage 1: Identification of Variables, Data Gathering and Study Design}

The initial step in this research involved the identification of variables required to analyse the extent of harvest or production and changes at the national level from 1990 to 2017. The variables consist of socio-economic and environmental information of food gaps, nutrition distribution, quantity, number of food insecure, macroeconomic indicators, population food insecure, share of population food insecure in percentage, total grains/cereal, root crop, production quantity, grain equivalent, and food availability per capita $\mathrm{kg} / \mathrm{cap}$, the total size of cultivated area and the average. The others consist of food supply grain equivalent, area harvested, import quantity, export quantity, import monetary value, total grains and cereals, number of people undernourished, proportion of undernourished in total population in $\%$, the percentage changes in undernourished, and regional distribution of the number of undernourished. Added to that, are the food security target, averages in the population of undernourished people, food gap per capita, food gap total, food insecurity scale, food deficit distribution, vitamin deficiency among pregnant women and children, per capita calorie supply, fish export and progress towards food security. These variables as mentioned earlier were derived from secondary sources made up of government documents, newsletters and other documents from NGOs. This process was followed by the design of data matrices for socio-economic and land use (environmental) variables covering the census periods from 1990, 2000, 2002 to 2007, 2010 to 2017. The design of spatial data for the GIS analysis required the delineation of country boundary lines within the study area as well. Given that the official boundary lines between the 10 countries remained the same, a common geographic identifier code was assigned to each of the area units for analytical coherency.

\subsection{Stage 2: Data Analysis and GIS Mapping}

In the second stage, descriptive statistics and spatial analysis were employed to transform the original socio-economic and ecological data into relative measures (percentages, ratios and rates). This process generated the parameters for establishing, the extent of food security deficits, and production and areas cultivated, and others faced with changes in harvests, food availability, number of people undernourished and the trends across the region for each of the 10 countries through measurement and comparisons overtime. While the spatial units of analysis consist of countries, region and the boundary and locations where food harvests, export and imports activities and the proportion of undernourished flourished, this approach allows the detection of change, while the graphics highlight the actual frequency and averages, impacts, share of population food insecure, and regional distribution of the number of undernourished, the intensity of operations and the trends as well as the monetary equivalents. The 
remaining steps involve spatial analysis and output (maps-tables-text) covering the study period, using Arc GIS 10.4 and SPSS 10.4. With spatial units of analysis covered in 10 countries (Figure 1), the study area map indicates boundary limits of the units and their geographic locations. The outputs for each country were not only mapped and compared across time, but the geographic data for the units which covered boundaries, also includes ecological data of land cover files and paper and digital maps from 1990-2017. This process helped show the spatial evolution of various occurrences that sparked the dispersion of vitamin deficiency, the diffusion of food security predictors, the concentration of food security index, and farm output. The other products from the mapping also consist of the ensuing environmental and economic trends, climactic risks as well as changes in other variables driving food security challenges and impacts in the study area.

\section{Results}

This section of the paper presents the results of the data analysis on the changing food security situation in the study area. There is a prime emphasis on the temporal highlights of production, projected food security gaps, the threats of undernourishment and the exposure to malnutrition, extent of insecurity. This is followed by an account of the impacts of food insecurity within the West African region. The others consist of the identification of factors impeding food security in the respective places over time, GIS mapping and the initiatives of various agencies to contain food insecurity.

Table 2. Food Security Trends and Indicators in West Africa, 1990-2012

\begin{tabular}{|c|c|c|c|c|c|c|c|c|}
\hline Year & PQGE. & FAPC- & FSG & AH & IQ & EQ & IV & IUV\$ \\
\hline 1990 & 37637 & 1853.87 & 40980 & 35610 & 3330.62 & 306 & 706.48 & 2019.81 \\
\hline 2000 & 55835.77 & 1746.51 & 62382 & 44424.32 & 8428.57 & 1619.44 & 1023.69 & 1354.6 \\
\hline 2010 & 79619 & 2058.89 & 92397 & 51817 & 12725.71 & 2628.23 & 3808.94 & 2898.54 \\
\hline 2012 & 79603 & 2108.93 & 93709 & 56365 & 14072.25 & 1868.16 & 6386.69 & 4658.86 \\
\hline Tot & 252694.77 & 7768.2 & 289468 & 188216.3 & 38557.15 & 6421.83 & 11925.8 & 10931.81 \\
\hline
\end{tabular}

Source: FAO/GIEWS, 2016, USDA, ERS 2016

Table 3. Food Security Indicators in West Africa, 1990

\begin{tabular}{|c|c|c|c|c|c|c|c|c|}
\hline Nat & PQGE. & FAPC- & FSGE- & AH & IQ & EQ & IV & IUV\$ \\
\hline Be & 1240 & 184.12 & 1438 & 863 & 198.05 & 117.50 & 53.83 & 271.80 \\
\hline B F & 1523 & 195.38 & 1734 & 2539 & 210.30 & 4.33 & 35.85 & 170.49 \\
\hline Chad & 819 & 131.04 & 880 & 1199 & 61.27 & 0.00 & 6.90 & 112.62 \\
\hline Iv C & 2489 & 204.83 & 3061 & 1919 & 569.20 & 10.00 & 163.32 & 286.93 \\
\hline Gha & 2319 & 157.29 & 2666 & 1437 & 347.15 & 15.00 & 68.20 & 196.46 \\
\hline Libe & 197 & 182.80 & 341 & 235 & 143.50 & 0.00 & 25.15 & 175.23 \\
\hline Nige & 1487 & 227.03 & 1723 & 6903 & 231.50 & 26.67 & 34.77 & 150.21 \\
\hline Niga & 25800 & 194.51 & 26611 & 18487 & 811.00 & 90.00 & 113.37 & 139.79 \\
\hline Sene & 926 & 186.48 & 1568 & 1250 & 637.50 & 0.00 & 175.99 & 276.05 \\
\hline Togo & 837 & 190.39 & 958 & 778 & 121.15 & 42.50 & 29.10 & 240.23 \\
\hline Tot & 37637 & 1853.87 & 40980 & 35610 & 3330.62 & 306 & 706.48 & 2019.81 \\
\hline
\end{tabular}

Table 4. Food Security Indicators in West Africa, 2000

\begin{tabular}{|c|c|c|c|c|c|c|c|c|}
\hline Nat & PQGE. & FAPC- & FSGE- & AH & IQ & EQ & IV & IUV\$/mt \\
\hline Ben & 2405 & 210.99 & 2544 & 1290 & 139.50 & 64.10 & 18.85 & 135.14 \\
\hline BuF & 2269 & 202.13 & 2667 & 2673 & 398.20 & 18.27 & 56.99 & 143.13 \\
\hline Chad & 1094 & 141.57 & 1205 & 1847 & 111.10 & 0.00 & 7.10 & 63.91 \\
\hline Iv C & 3197 & 203.00 & 4154 & 1606 & 951.05 & 24.20 & 142.86 & 150.21 \\
\hline Gha & 6039 & 238.81 & 6739 & 2543 & 698.80 & 9.00 & 98.65 & 141.18 \\
\hline Libe & 282 & 139.77 & 439 & 218 & 156.80 & 0.00 & 33.80 & 215.56 \\
\hline Nige & 2190 & 203.76 & 2553 & 7356 & 237.47 & 81.77 & 37.16 & 106.94 \\
\hline Niga & 36217 & 212.98 & 39790 & 25811 & 3572.65 & 140.00 & 468.29 & 131.08 \\
\hline Sene & 1002.77 & 0.00 & 1040 & 181.32 & 2052 & 1201 & 146.52 & 146.11 \\
\hline Togo & 1140 & 193.50 & 1251 & 899 & 111.00 & 81.10 & 13.47 & 121.34 \\
\hline Tot & 55835.77 & 1746.51 & 62382 & 44424.32 & 8428.57 & 1619.44 & 1023.69 & 1354.6 \\
\hline
\end{tabular}

Source: FAO/GIEWS, 2016, USDA, ERS 2016 
Table 5. Food Security Indicators in West Africa, 2010

\begin{tabular}{|c|c|c|c|c|c|c|c|c|}
\hline Nat & PQGE. & FAPC- & FSGE- & AH & IQ & EQ & IV & IUV\$ /mt \\
\hline Ben & 3215 & 212.58 & 3487 & 1617 & 270.90 & 105.00 & 92.06 & 339.82 \\
\hline BFa & 4534 & 225.57 & 4954 & 4320 & 416.56 & 325.00 & 101.97 & 244.80 \\
\hline Chad & 3460 & 146.49 & 3691 & 2662 & 231.30 & 450.00 & 47.63 & 205.92 \\
\hline Iv C & 3710 & 220.71 & 5327 & 2129 & 1608.40 & 58.40 & 615.90 & 382.92 \\
\hline Gha & 9558 & 236.12 & 10478 & 3141 & 918.20 & 271.20 & 333.83 & 363.57 \\
\hline Libe & 360 & 169.11 & 739 & 320 & 378.60 & 0.00 & 144.81 & 382.49 \\
\hline Nige & 5656 & 261.86 & 6097 & 10640 & 433.80 & 200.00 & 115.33 & 265.85 \\
\hline Niga & 45882 & 180.82 & 52706 & 24363 & 6820.00 & 1100.00 & 1876.22 & 275.10 \\
\hline Sene & 1668 & 202.42 & 3115 & 1507 & 1422.00 & 28.00 & 454.41 & 319.56 \\
\hline Togo & 1576 & 203.21 & 1803 & 1118 & 225.95 & 90.63 & 26.78 & 118.51 \\
\hline Tot & 79619 & 2058.89 & 92397 & 51817 & 12725.71 & 2628.23 & 3808.94 & 2898.54 \\
\hline
\end{tabular}

Source: FAO/GIEWS 2016, USDA, ERS 2016

Table 6. Food Security Indicators in West Africa, 2012

\begin{tabular}{|c|c|c|c|c|c|c|c|c|}
\hline Nat & PQGE. & FAPC- & FSGE- & AH & IQ & EQ & IV & IUV\$ /mt \\
\hline Ben & 3510 & 219.42 & 3838 & 1607 & 328.00 & 105.00 & 366.42 & 1117.14 \\
\hline BFa & 4860 & 235.06 & 5488 & 4100 & 623.21 & 262.79 & 168.33 & 270.10 \\
\hline Chad & 3390 & 148.21 & 3568 & 3809 & 177.80 & 475.00 & 50.82 & 285.83 \\
\hline IvC & 3873 & 229.85 & 5655 & 2144 & 1770.60 & 44.40 & 1377.19 & 777.81 \\
\hline Gha & 9986 & 247.22 & 11033 & 3200 & 1045.00 & 170.00 & 430.95 & 412.40 \\
\hline Libe & 365 & 166.14 & 810 & 321 & 444.80 & 0.00 & 146.78 & 329.99 \\
\hline Nige & 5393 & 247.06 & 5911 & 10249 & 511.88 & 100.00 & 220.38 & 430.52 \\
\hline Niga & 45032 & 189.33 & 52359 & 28188 & 7320.00 & 600.00 & 2871.84 & 392.33 \\
\hline Sene & 1359 & 205.44 & 2984 & 1255 & 1625.00 & 20.90 & 707.07 & 435.12 \\
\hline Togo & 1835 & 221.20 & 2063 & 1492 & 225.96 & 90.07 & 46.91 & 207.62 \\
\hline Tot & 79603 & 2108.93 & 93709 & 56365 & 14072.25 & 1868.16 & 6386.69 & 4658.86 \\
\hline
\end{tabular}

Source: FAO/GIEWS, 2016, USDA, ERS 2016

\subsection{Food Production Trends and Security 1990-2012}

The food security indicators of the study area all through 1990 to 2012 from production to import remains in the upswing as depicted in all categories for the nations in the zone (Table 2-6). At the same time, the region's overall grain production, food availability and supply and area harvested were in the order of $252694.77 \mathrm{MT}$ to $7768.2 \mathrm{~kg}, 289468 \mathrm{MT}$ and $188216.3 \mathrm{ha}$, while imported food surpassed export by sizable margins of 38557.15 to 6421.83 MT. Besides the monetary and unit values for import ( $\$ 11,925.8$ million and 10931.81MT) (Table 2), the distribution of critical food security indictors in the region, from 1990-2012 indicates that in the fiscal years 1990 and 2012, the volume of food production, food availability, supply and land area harvested rose amply from $37637-79603 \mathrm{MT}$ to $1853.87-2108.93 \mathrm{~kg}$, and 40980-93709 MT to 35610- 56365 ha (Table 2, 3-6). While there is no effort here to recant all that transpired in 2000-2012 for all the nations due to lack of space, in the year 2000 , the core indicators (production, availability, supply, harvested area) in the region for that period held firm at
55835.77 MT, 1746.51, $\mathrm{kg}$ 62382, MT and 44424.32 ha respectively with export and import categories at varying levels as well (Table 4). Note that, the grain output for 2010 at 79619 MT remained sizable followed by the available food per capita and grain supply and harvested area estimated at $2058.89 \mathrm{~kg}, 92397$ MT and 51817 hectares. During the same time, the region's export volumes stayed at active levels as well (Table 5). At the country level, Nigeria as the largest agricultural and food producing nation in the region, had vast output, food availability, supply and harvested areas in 1990 which hovered around 25800 MT to $194.51 \mathrm{~kg}$ and 26611 Mt to $18487 \mathrm{ha}$. (Table 3). During that period, import and export quantities and dollar equivalent of import values stood at 811.00 to $90.00 \mathrm{MT}$ and $\$ 113.37$ to $\$ 139.79$ (Table 3). While Nigeria's core indicators for 2000 outpaced the ones in 1990, the rebound in 2010 among those same indicators is a testament to the nation's potentials in the food sector of the region (Table 5). Furthermore, in 2012, Nigeria's production quantity, food availability, supply and harvested areas jumped significantly (Table 6). The values ranged from $45032 \mathrm{MT}$ to $189.33 \mathrm{~kg}, 52359 \mathrm{MT}$ and 28188 
ha and continued with import and export and import dollar values of 7320.00 to $600.00 \mathrm{MT}$ and 2871.84 to 392.23 million dollars (Table 6). Of great importance in all these years is Nigeria's dominance in food farming and its share of the region's critical food security indicators (production quantity, availability, and supply) when compared to the others from Benin to Senegal (Table 3-6). The breakdown which stands at $61.87 \%, 60.40 \%$ and $57.75 \%$ supersedes the levels of the other nations in the region (Figure 2).

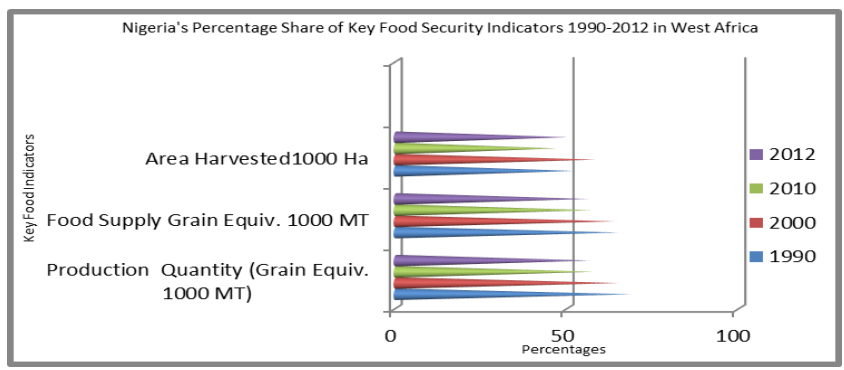

Figure 2. Summary of Nigeria's Food Security Indicators, 1990-2012

\subsection{The Projected Food Security Situation and Gaps in West Africa 2017-2027}

The projected food security trends centers on population growth and gaps among the countries in the study area from 2017 to 2017 (Table 7-7.1). Taking into consideration the evolution in food security parameters and the trends from 2017 to 2027. See that aside from a teeming population projection of 331.8 to 419.5 million people from 2017 to 2027 in the region, the population of food insecure citizens seems destined to slide from 37.9 to 27.9 million in West Africa over time. At that level, the same point holds at the country level where 9 of 10 nations in the region will see their rate and share of total population exposed to food insecurity plummet in the years 2017-2027 (Table 7). Under that scenario, the biggest drops ( 25.4 to $16.9 \%, 14.4$ to $7.2 \%$, and 14.6 to $7.0 \%$ ) in percentage share of populations threatened by insecurity among the countries are notable in Burkina Faso, Ivory Coast and Niger. Added to that list are the nations of Senegal and Togo where food insecurity vulnerability is on track to decline from 14.3 to $7.1 \%$ and 20.9 to $14.7 \%$ respectively by 2017 through 2027 (Table 7). The anticipated declines in both Ghana and Nigeria stands at 6.6 to 0.9 and 5.5 to $2.5 \%$ during the same periods. Pertaining to the perceived deficits in food outputs, the apparent gaps among the countries percapita in kilo calorie per day and food gap total in TMT reflects visible changes. These includes potential fluctuations of 5572 and 3117 $\mathrm{kcal} / \mathrm{day}$ and 1586 to 1134 TMT from 2017 and 2027 (Table 7.1). While during that period, food gap indicators are projected to remain in declines among the individual countries. The largest food producing nation in the region, Nigeria will see its daily food gap per capital and the quantity of total food gap drop from 208 to $187 \mathrm{kcal} /$ day and 256 and
135 TMT between 2017 to 2027 (Table 7.1). The smaller nations of Liberia and Togo deemed to have exhibited similar patterns in the projected food gap numbers will see their indices vary from 713 to $580 \mathrm{kcal}$ and 223 to 163 TMT (for the former) and 312 to $286 \mathrm{kcal}$ and 62 to 51TMT (for the later) within the same period of 2017-2027.

\subsection{The Threats of Undernourishment 1990-2016}

Aside from the progress in the region towards self-sufficiency in food production, the exposure to undernourishment was quite rife. This is evident with the proportion and number of people deemed vulnerable in the region (Table 7-7.1). The proportion of undernourished persons in total population as the table indicates seems highly concentrated in Benin, Burkina Faso, Liberia and Chad, Niger, Senegal, and Togo. This is different compared to the nations represented in the single digit values. The temporal distribution of undernourishment rates among countries in the region also points to a regional average of $22.21 \%$ between 1990 through 2016. With the average proportions mostly in double digits levels, from 1990 to 2016, the two nations (Chad and Liberia) fully impacted by exposures to the threats of undernourishment among the populations, outpaced their neighbours in West Africa. During those years, when Chad and Liberia averaged 42.68 to 34.4 in the percentage of underfed citizens, another second tier of nations Burkina Faso, Senegal and Togo followed up with 22.54-24.3\%. Except for the 9.98\% of Nigeria's population that are vulnerable, the remaining areas where the proportion of malnourishment reached notable levels $(13.78 \%$ to $16.86 \%)$ in the same time frame comprises of Benin, Ghana, Niger and Ivory Coast (Figure 3). With time, the total number of undernourished people from 1990-1992 and 2000-2002, ranged from 42.9 to 33.1 million and continued at 30.1 to 32.6 million by 2005-2007, 2010-2012 and 2014-2016. Another interesting point of importance in all these years is that the estimates for Nigeria mostly in tens of millions (20.8 to $11.2,9.3$ and 10.2 to 12.9 million) in 1990-1992 to 2014-2016 surpassed those of the other nations. In neighbouring Benin, the population of poorly fed individuals fluctuated from the opening values of 1.5, 1.6, 1.3 million to 1.2 and 0.8 million from 1990 to 2016. In the periods 1990-1992 and 2002-2002, the situation in Burkina Faso and Chad showed that the both nations also had many citizens classified as underfed over the years. In the case of Burkina Faso, the initial numbers stood at 2.4 to 3.3 million people and another 3.5 to 3.5 million in 1990-1992 through 2005-2007 and 2010-2012, followed by another 3.7 million all through 2014 to 2016. For Chad, the human exposures to malnutrition were around 3.6 to 3.5 million citizens in 1990-1992 to 2000-2002 and it continued at over 4 million plus (4.1, 4.8, 4.7 million) in the ensuing years 2005-2007, 2010-2012 and 2014-2016 (Table 8). 
Table 7. Food Security Indicators Country Indicators, 2017-2027

\begin{tabular}{|c|c|c|c|c|c|c|}
\hline & \multicolumn{2}{|c|}{ Population } & \multicolumn{2}{c|}{ Population Food insecure } & \multicolumn{2}{c|}{$\begin{array}{c}\text { Share of Population food } \\
\text { insecure in \% }\end{array}$} \\
\hline Nations & 2017 & 2027 & 2017 & 2027 & 2017 & 2027 \\
\hline Benin & 11.0 & 14.2 & 1.4 & 1.3 & 12.3 & 8.9 \\
\hline Burkina Faso & 20.1 & 26.8 & 5.1 & 4.5 & 25.4 & 16.9 \\
\hline Chad & 12.1 & 14.4 & 5.9 & $6.1 *$ & 49.2 & 42.3 \\
\hline Ivory Coast & 24.2 & 28.5 & 3.5 & 2.1 & 14.4 & 7.2 \\
\hline Ghana & 27.5 & 34.0 & 1.8 & 0.3 & 6.6 & 0.9 \\
\hline Liberia & 4.4 & 5.5 & 3.1 & 2.8 & 1.8 & 14.6 \\
\hline Niger & 19.2 & 26.1 & 2.8 & 1.8 & 14.6 & 7.0 \\
\hline Nigeria & 190.6 & 241.5 & 10.5 & 6.2 & 5.5 & 2.5 \\
\hline Senegal & 14.7 & 18.3 & 2.1 & 1.3 & 14.3 & 7.1 \\
\hline Togo & 8.0 & 10.2 & 1.7 & 1.5 & 20.9 & 14.7 \\
\hline Study Area & 331.8 & 419.5 & 37.9 & 27.9 & 165 & 122.1 \\
\hline
\end{tabular}

Source: USDA, 2017

Table 7.1. List of Countries and Their Food Gaps 2017-2027 (in 1,000 tons)

\begin{tabular}{|c|c|c|c|c|}
\hline & \multicolumn{2}{|c|}{ Food gap (per capita) kcal/day } & \multicolumn{2}{c|}{ Food Gap Total (1000 TMT) 2027* } \\
\hline Nations & 2017 & 2027 & 2017 & 2027 \\
\hline Benin & 267 & 250 & 40 & 35 \\
\hline Burkina Faso & 433 & 390 & 276 & 221 \\
\hline Chad & 507 & 473 & 373 & 357 \\
\hline Ivory Coast & 360 & 317 & 143 & 74 \\
\hline Ghana & 238 & 185 & 49 & 163 \\
\hline Liberia & 713 & 580 & 223 & 59 \\
\hline Niger & 277 & 240 & 105 & 135 \\
\hline Nigeria & 208 & 187 & 256 & 32 \\
\hline Senegal & 240 & 209 & 59 & 51 \\
\hline Togo & 312 & 286 & 62 & 1134 \\
\hline Study Area & 5572 & 3117 & 1586 & \\
\hline
\end{tabular}

Source: USDA, 2017

Table 8. Number of People Undernourished in Millions

\begin{tabular}{|c|c|c|c|c|c|c|}
\hline Nations & $1990-92$ & $2000-02$ & $2005-07$ & $2010-12$ & $2014-16$ & Change $\%$ \\
\hline Benin & 1.5 & 1.6 & 1.3 & 1.2 & 0.8 & -44.3 \\
\hline Burkina Faso & 2.4 & 3.3 & 3.5 & 3.5 & 3.7 & 57.9 \\
\hline Chad & 3.6 & 3.5 & 4.1 & 4.8 & 4.7 & 28.8 \\
\hline Ivory Coast & 1.3 & 2.7 & 2.5 & 2.8 & 2.8 & 111.8 \\
\hline Ghana & 7.1 & 3.1 & 2.3 & 1.4 & 0 & $<-50$ \\
\hline Liberia & 0.6 & 1.1 & 1.3 & 1.4 & 1.4 & 139.6 \\
\hline Niger & 2.2 & 2.3 & 2 & 1.7 & 1.8 & -18.0 \\
\hline Nigeria & 20.8 & 11.2 & 9.3 & 10.2 & 12.9 & -38.1 \\
\hline Senegal & 1.9 & 2.9 & 2.4 & 1.9 & 3.7 & 93.1 \\
\hline Togo & 1.5 & 1.4 & 1.4 & 1.2 & 0.8 & -44.6 \\
\hline Study Area & 42.9 & 33.1 & 30.1 & 30.1 & 32.6 & NA \\
\hline
\end{tabular}

Source: FAO, 2015 


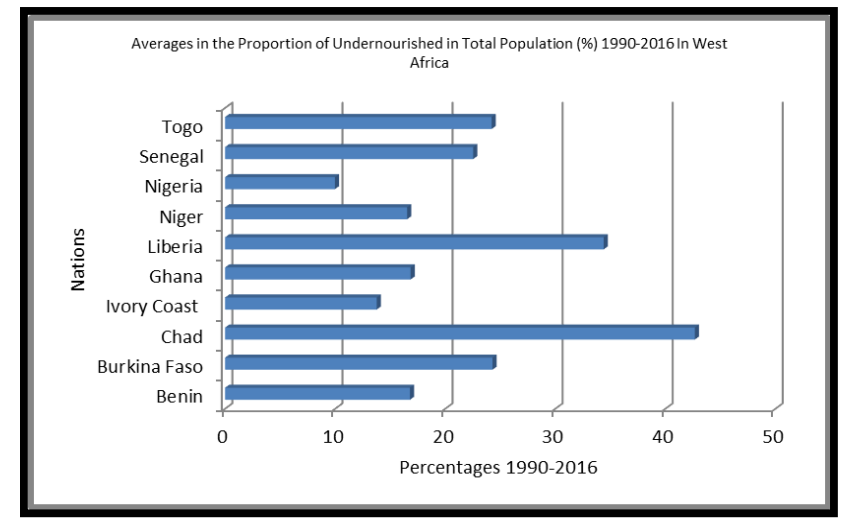

Figure 3. Averages in the Proportion of Undernourished Population

\subsection{Exposure to Malnutrition and Assessment of Food Insecurity in Other Places}

In the other areas, the malnutrition numbers for Ivory Coast varied by 1.3 to 2.7 and 2.5 million coupled with identical population size of 2.8 million in 2010-2012 and 2014 through 2016. In the same order, Ghana's share of undernourished citizens started at 7.1 million to 3.1 million and 2.3 million around 1990 to 1992,2000 through 2002 and 2005 to 2007 , by 2010 to 2012 and 2014 to 2016, the numbers dropped from 14 million to 0 . Aside from Niger and Senegal where the population of poorly fed individuals exceeded 2 million in some of the years, the numbers faded in the lower West African nations of Benin and Togo. The nation of Liberia on the other hand, also saw much lesser numbers of 0.6 to 1.1 million and 1.3 to 1.4 million during the periods 1990-2016.

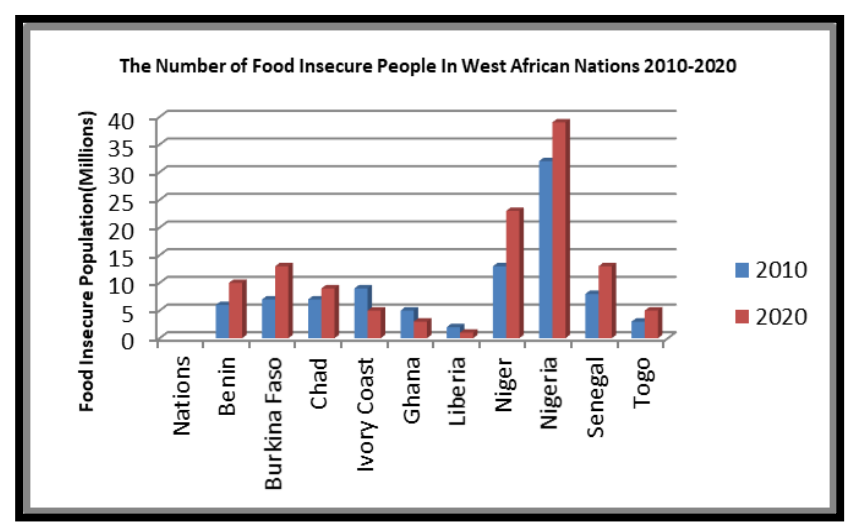

Figure 4. Number of Food Insecure People in West Africa

Looking at the percentage changes in malnourished citizens so far, there exists an even split of 4 to $5 \%$ regarding increases and declines among the nations. From the table, Benin, Ghana, Niger, Niger and Nigeria and Togo all posted declines $(-44.3$, to $<-50,-18.0$ to -38.1 and $-44.6 \%)$ in the number of poorly fed citizens while Burkina Faso, Chad, Ivory Coast and Senegal also saw a surge of 57.9, 28.8, 111.8 to $93 \%$ (Table 8 ). Another twist to the food insecurity problem in the West African region, involves the number of food insecure people. Of the total of 92 to 121 million citizens on that list in 2010 and 2020. Nigeria and Niger will lead the others by $32-39$ million and 13 and 23 million respectively. The plights of food insecure countries in the study area also extends to Burkina Faso, Senegal, Benin and Chad with those in that category listed as 8 to 13,7 million and 13, 7, 9 million people respectively. Regarding the nations on the lower end of food insecurity, Ghana, Liberia and Togo did stand out with fewer number of citizens estimated at 5, 3, and 2 to 1 million in that grouping. Furthermore, the info on food gaps in the countries involving nutrition and distribution from 2010 to 2020 covers notable items even though it appeared somewhat negligible in certain areas (Figure 4).

\subsection{Impact Assessment}

Based the ongoing analysis, it is apparent that the West African region did encounter notable events that are threatening the food sector with far reaching consequences across time. The coverage herein delves on poverty, social unrest, famine, undernourishment and forced migration.

The incidence of poverty as a product of food insecurity remains obvious in the study area over the last several years. In 2007 to 2008, rocketing prices ranked high among the most obvious symptoms of global food crisis which often put those at the margin on the receiving end. The emergent pressures and hardships from it have sparked riots in many countries with threats to the existing social and political order at the expense of the poor. The gravity of the situation did get so bad that the World Bank stated that the spike in food prices has pushed 44 million people into extreme poverty since June 2010. Concerned about the dangers to the welfare of citizens, the FAO warned that in the absence of an immediate intervention, poor nations like Mali and Niger in the West African region are extremely vulnerable to instability because of rising prices. The issues stem from genuine concerns as to how misguided government policies often lead to a worsening of the situation through unnecessary stockpiling of food by some countries or agricultural export bans. Seeing that these policies discourage investment in production, there is always the unnecessary exposure of citizens to the poverty and misery associated with food insecurity. Because these problems are not confined solely to impoverished areas, the middle class in some of the wealthy areas of West Africa are also threatened by the insecurity from rising costs of basic food items like rice, tomatoes and onions that come mostly from the arid Northern areas [5].

Bearing in mind the daily essence of nutrition in the collective experience of many places in the study area, one need not lose sight of the dangers posed by the food deprivations to public order. From what transpired in the past, the occurrence of social unrest and food riots across nations whenever extreme food insecurity threatens citizens, does remind everyone that it should no longer be ignored. Not too long ago in the West African region, rioters in Burkina Faso wasted little or no time in massive protests over a $65 \%$ rise in the price of some foodstuffs on February 20 in 2008. In 
making their voices heard during that time, the demonstrators burnt government buildings and looted stores. Just a few days later, in a nearby nation, a taxi drivers' strike over fuel prices turned into a massive protest over soaring food prices. This left around 20 people dead while hundreds were arrested. During the month of March in 2008 in Senegal, police officers dressed in riot gear under calls to quell demonstrations, resorted to the use of tear gas and the beating up of people protesting high food prices. Based on the records, the police later raided a television station that aired images of the event throughout the country [60]. Furthermore, instances of social unrest resulting in the violent displacement of farming communities over the activities of nomadic cattle men in search of grazing land has spilled over to many communities in both Central and Southern Nigeria. From the ensuing social unrest in those places, the loss of lives and the dislocation of farmers whose products serve as food sources, create further hardships for communities. Such uncertainties in the arable Middle Belt and other areas in the South, trigger unwanted volatilities in the food sector hence the linkages [5].

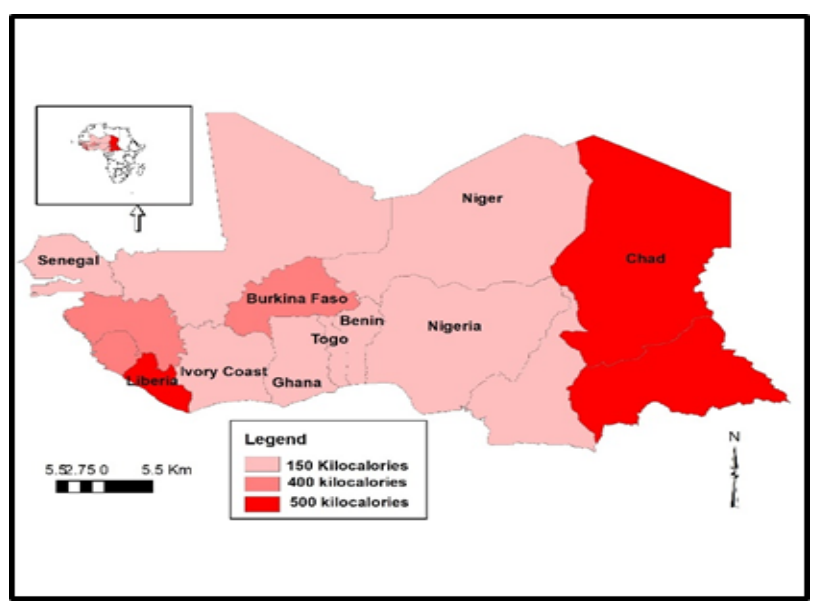

Figure 5. Depth of Food Deficit in West Africa, 2015

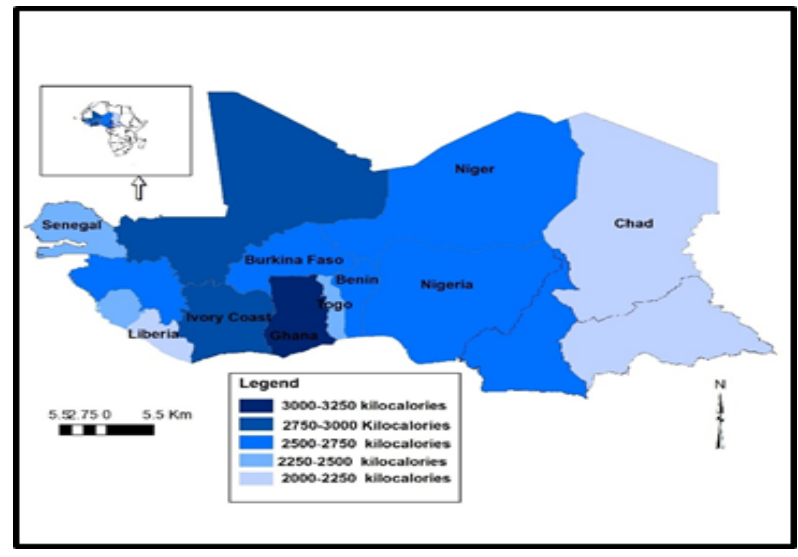

Figure 6. Daily Per Capita Caloric Intake, 2013

Looking at the gravity of current experiences, the deadly Sahel famines of 1973 and 1984 remains engraved in popular memoirs. The threats of food insecurity in those circumstances which limits the capacity to plant and till the land and feed in the region today is very different. On top of that, the region did not meet the first Millennium Development Goal (MDG) of halving the number of malnourished people by 2015 due to the incidence of food insecurity. According to current estimates, tens of millions of West African citizens are still undernourished, and many face food emergencies every year, during the lean season because of famine. The food crisis of 2007-2008, followed by rising international food prices, low production levels and a heavy reliance on food imports, has left West African nations vulnerable. At the same time, the frequency of extreme climate events and variability are also the leading challenges in the agricultural production process. This is impeding food security in arid areas, where declines in annual rainfall and encroaching desertification threaten the resilience of populations in the ecosystem. This specific factor is linked with the increased southward migration by pastoralists for grazing grounds with the ensuing armed conflicts and excessive population pressures on land resources, while also exposing the herds to pests. For that, the ecological spill overs have led to the displacement of host communities by herdsmen and insecurity in some places $[5,62]$.

\subsection{GIS Mapping and Spatial Analysis}

The geo visual analytics in this section captures the spatial patterns of food deficits and level of caloric intake, vitamin deficiency among mothers and children in a manner not seen before. Of great interest are the calibration of food security index and the dangers posed by drought, the spatial dimensions of fish export and variations in farm output. Considering the extent of food deficit crisis over the years based on the number of calories needed for every person to be lifted from deprivation status in the region. The spatial distribution of the situation in 2015, points to plethora of points in space where lower kilocalories requirements were obvious from Niger and Senegal in the Northwest followed by further extension into Nigeria along the Southeast corner of the map. From there comes more spread of the 150 kilocalories category onto the neighbouring central and lower south nations of Benin, Togo Ghana and Ivory Coast on the south west. This is in deep contrast to the three other nations (Burkina Faso, Chad, and Liberia) where higher calorie intakes measured at 400 to 500 Kilocalories are required per person. From the patterns in the map, it is evident that aside from a much higher presence of lower calorie requirements per person fully concentrated among four nations of the lower Southern axis of the region with a few clusters on the upper portion of the map. The higher food calorie categories seemed slightly distributed from the South to the North central zone of the study area as well (Figure 5). In a similar vein, the next map highlights the distribution of daily per capita average caloric supply for each person in the countries of the West African region in 2013. The region's caloric supply patterns that year seems dominated by a duo of nations initially, coupled with an even split of 4-3 between 
the other group of countries. Of the areas in the region, note that the caloric availability of food sent to the households under the dark and light blue colours were more pronounced in the Lower South neighbouring countries of Ghana and Ivory Coast. At that time, much of the households in the former took in the largest volume of food made available to the tune of 3000-3250 kilo calories in the region as the later held on to sizable supply of nutriment in the order of 2500-2750 kilocalories. Elsewhere, the next level of daily per capital food distribution as denoted in purple colour categories (2500-2750 to 2250-2500 kilocalories) were quite visible in 5 countries (Niger, Nigeria, Benin and Burkina Faso and Senegal). This involves a gradual dispersal towards the upper North side of the map to the South and central zones and the upper west nation of Senegal. The remaining trio of nations (Chad, Togo, and Liberia) covered in lighter blue shades rounded out the lower scales of 2000-2250 in daily calorie supplied per person. Having shown the daily per capita caloric intake visually across the region, bear in mind also that this may imply the size of calories consumed as food can be wasted all too often at the consumer level (Figure 6).

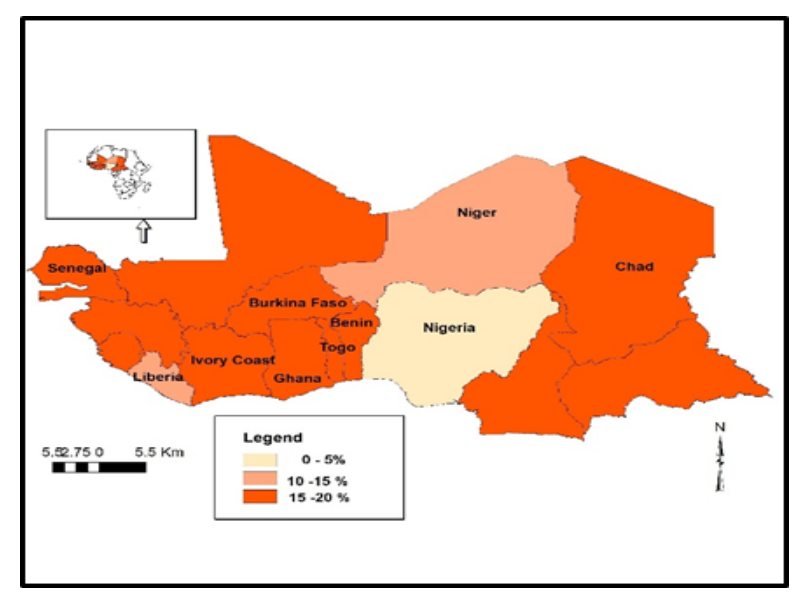

Figure 7. Vitamin A Deficits in Pregnant Women 1995-2015

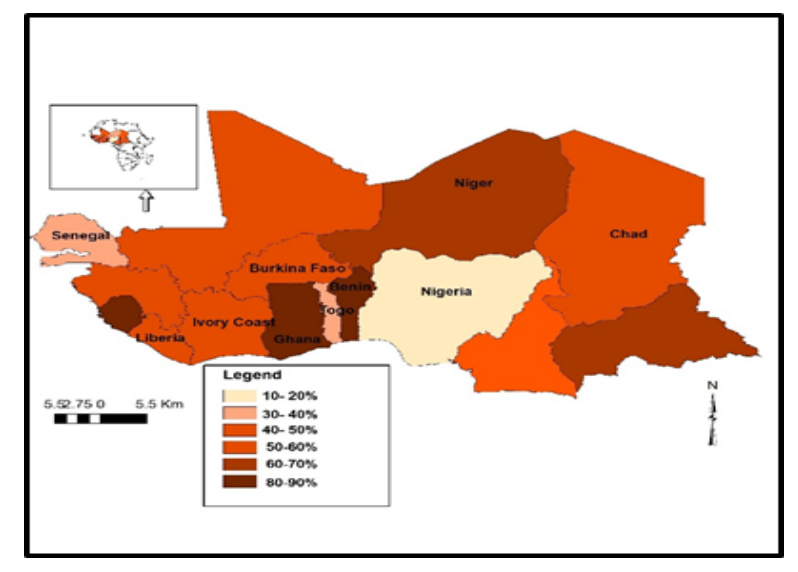

Figure 8. Prevalence of Vitamin A deficiency in Children, 1995-2015

Added to that, the incidence of vitamin A shortage among expectant mothers measured as the percentage of women showing serum retinal level of $0.7 \mathrm{umol}$ remains common in the West African region. Being key maternal health care challenge that saddles most families these days, between the periods of 1995-2015 as the map indicates, the study area saw a tri scale spread pattern that involved a mix of slight, significant and major forms of deficiencies synonymous with pregnant women in the nations of West Africa. Considering the dangers posed to the health of mothers and the unborn child, Nigeria in light yellow in the lower south accounted for a much lower level of $0-5 \%$ cases of pregnant women that experienced vitamin A deficits. Nigeria's situation appears minuscule compared to its neighbours (Niger and Liberia) in the upper North and South west parts of the region where the rate of vitamin A shortfall among pregnant mothers stood at 0-15 from 1995-2015. Elsewhere, the remaining $15-20 \%$ in vitamin A deficiency cases among expectant mothers in the region of West Africa were firmly concentrated in 7 nations (Chad, Senegal, Ivory Coast, Ghana, Togo, Benin, and Burkina Faso) represented in orange colour along the south, north, central and western parts of the study area. The biggest worry comes from the relative closeness involved in terms of the spread patterns regarding 5 of those nations especially Ivory Coast, Ghana, Togo, Benin, and Burkina Faso with similar cultural and ethnic ties. If that is the case, then there is an opportunity to probe deeper into the spatial auto correlations of the emergent patterns in order to ascertain if the prevailing cultural practices and beliefs is a predictor of these problems in the region among pregnant women (Figure 7). Knowing full well that $10-90 \%$ scale in vitamin A deficiency among pre-schoolers under 5 years equals to the percentage of those having a serum retinol level of $<0.7$ umol. Nigeria as distinguished in yellow in the lower South corner of the map once again, held on to the lowest cases (10-20\%) of vitamin A deficiency among children in the West African region. The deficit levels for the next group of countries (Senegal and Togo in the Upper West and Central parts of region) stood at $30-40 \%$ during the same periods in 1995-2005, while four other nations most notably Chad, Burkina Faso, Ivory Coast and Liberia accounted for $40-50 \%$ of the vitamin deficits for kids in the area. In those years, the largest forms of children's vitamin deficiency represented in light and dark brown at notable scales $(60-70 \%$ to $80-90 \%)$ as the map reveals, started from up north in Niger Republic until it moved further south onto Benin and Ghana. Having said that, vitamin deficiency all through the decade was fully dispersed at various levels all over the countries of the West African region. As a public health issue, this remains a major concern considering the spatial distribution from the North to the Southern axis of the region (Figure 8).

The food security index for 2015 shows, 5 different categories of which 4 are applicable on various scales of very low to high distributed across the regions from South to the North. Among these nations, Ghana represented in the white colour occupied the front pole with sole score of $<5 \%$ in the very low category followed by a quartet of nations (Niger, Nigeria, Benin, and Ivory Coast) listed as $5-14.9 \%$ under the 
moderately low-level colour of pink in nutrition security index. In the next level, spots of moderately high to high scales $(15-24.9 \%$ to $25-34.9 \%)$ in food security index were initially clustered around Togo, Burkina Faso, and Senegal followed by Chad and Liberia under the fourth level with the last one in dark brown (Figure 9). Looking at the propensity of drought in a region prone to the risks of changing weather patterns from 1990-2004. The three nations (Niger, Ivory and Liberia) represented in very light green colour in the Southern part along the West African zone saw the least number of (1-2) drought events. In the same 14-year span, another group of nations (Togo and Ghana) were scotched by severe drought on 3-5 occasions, while the drought events in neighbouring Benin Republic grew to 6-9. This seems somewhat close to the frequency of droughts as recorded in the upper Sahel region (Chad, Niger, Burkina Faso and parts of Senegal) where the numbers at $>10$ exceeded the rest of the nations in the study area. This does not come as a surprise considering the general characterizations of the West African region as the epicentre of extreme weather hazards in the past decade (Figure 10).

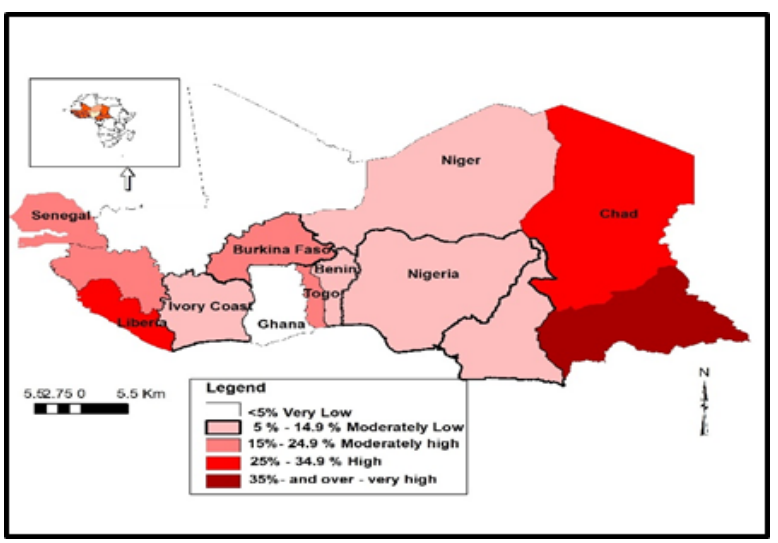

Figure 9. Food Security Index 2015

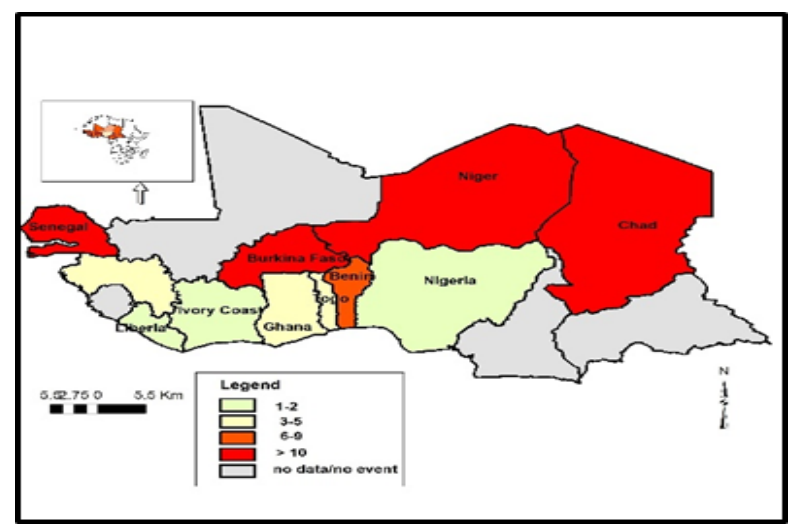

Figure 10. Drought Spells in West Africa, 1990-2004

In terms of net fish export as key source of protein and measure of food security and relative sufficiency during the 2004 period in the West Africa region. The countries classified in light green and yellow colours on the map (Niger, Nigeria, Benin, Togo, Ghana Ivory coast) are all ranked lower in net fish export compared to the leading country of Senegal in all categories. Being on the west side of the region with an Atlantic zone, during the period 2004, Senegal's net fish export of $10-31 \%$ exceeded the levels of all the other countries combined (Figure 11). Considering the anticipated variations in farm output by 2080 due to climate change in addition to carbon fertilization, see that the entire zone is listed in the colours of pink and red symbolizing the low to high deficits forms. From the map, the highest category of those changes in agricultural productivity represented in red at $-50 \%$, will not only be felt in the nations of Niger and Senegal in the North and West zones alongside Liberia in the coastal south. But the $-15 \%$ scale of the anticipated changes in farm output category by 2080 in the region will likely occur among a quartet of nations (Nigeria, Ghana, Ivory Coast, and Burkina Faso) (Figure 12).

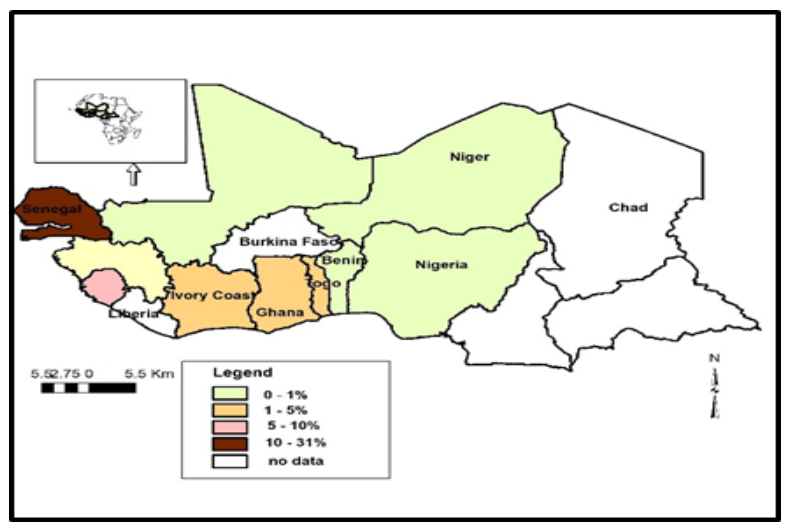

Figure 11. Export of Fish Products In West Africa, 2004

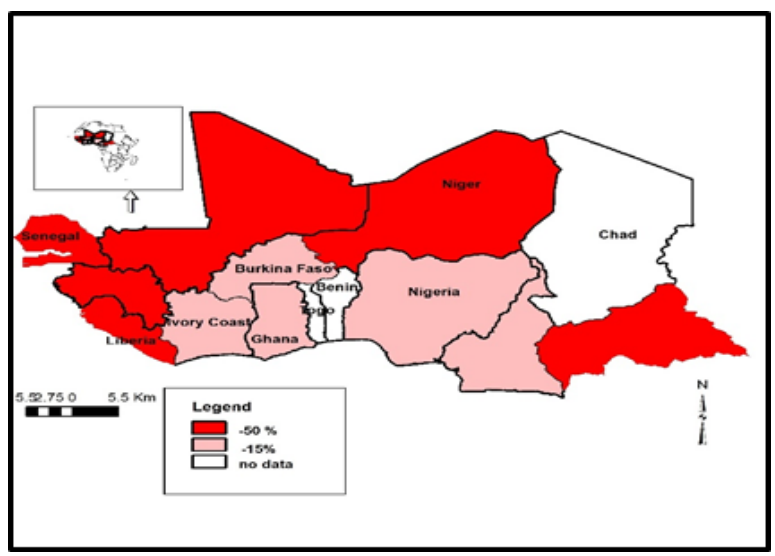

Figure 12. Changes in Farm Output in 2080 from Climate Change

\subsection{Factors Linked to Food Insecurity}

The threats of food insecurity do not operate in a vacuum in the study area. It is predicated on a set of policy, socio-economic, demographic, physical and environmental factors listed below.

\subsubsection{Policy Elements}

The growing incidence of food insecurity in West African will not be happening if not for a whole range of policy and economic elements hindering access among the populace in the respective countries. In some of the nations, current 
policies promote a system reliant on domestic food production sustained by overseas food imports. In a region where many depend on $40 \%$ of food imports to ensure enough rice supply, the matter is complicated by the limited free flow of farm goods across West Africa coupled with physical, infrastructural and political barriers as well as conflicts [62]. The problems in the region are further manifested by the fragmented nature of markets, the frequency of staple food shortages and price volatility. Notwithstanding the abundance of water resources throughout the West African region, there is also a clear deficit of investment in that area for agricultural purposes mainly through irrigation schemes. With only few countries meeting the target of official public spending in agriculture as required by the African Union. Much of the funding that go into agriculture from foreign technical and financial partners are often allocated without strict linkages to the domestic policy landscape. This perhaps explains well, the predominance in West Africa of a model of agriculture that favours cash crop production and export instead of an agricultural production type that supports food security, rural employment and integration into regional markets. Such a situation fosters an over reliance on the importation of cheaper food products for consumption, where farmers enjoy very lucrative subsidies that do not allow them to develop the local capacities to feed themselves. Lacking adequate regional policies to trade across borders, food producers in West Africa suffer from poorly managed transportation, warehousing and the lack of lines of credit [1]. This fragmentation also presents serious challenges that keep small farmers from producing excess crops to sell to the food industry amidst the lack of information on new agricultural technologies and best practices in the region $[1,5]$.

\subsubsection{Demography and Urbanization}

The role of socio-economic elements of demography and urbanization in precipitating the problems of food security in the Western African region need not be underestimated. Considering the challenges of making food available to a teeming population in lieu of mounting scarcity. The average yearly population growth rate of the West African countries under analysis at $2.78 \%$ is among the highest in the world. Nigeria as an example has been projected to have the third largest population growth in the world from 2000 to 2050 with the major urban centers the likely destinations of the increments. As such, urban development is continually changing the dynamics of food security and access in the region to the extent that the intensification of growth spill overs in many of the cities are continually influencing food security in many places. In 1950, West Africa had about 152 cities and major towns; today it has more than 12 times that number, or 1,947 cities. These includes Sub-Saharan Africa's largest city, Lagos, with over 20 million inhabitants [45]. This is putting heavy pressures through the conversion of available farm land to infrastructural amenities such as roads, bridges and houses to sustain new settlements.
Providing basic urban amenities for larger populations of that size under competing land uses in a shrinking agricultural space at current growth rates causes higher food demand in West Afric. The spatial dynamics that accompany urbanization in the area such as the geographic distribution of towns, their size, their number and the distances between them, are increasingly shaping food and nutritional security outcomes with pressures on food supply. Rural areas that are closer and better connected to cities have seen their available arable farm land converted to development because of the encroachment from rapid urbanization [45].

\subsubsection{Physical, Environmental and Climatic Factors}

Looking at the current conditions, there are several physical and ecological elements impeding enough food supply and domestic production in West Africa. Aside from the droughts, $55 \%$ of the land in Africa is unsuitable for any kind of agricultural activity except nomadic grazing. In that way, the soil distribution patterns and the physical attributes in the continent revealed that many of its soil types contain poor amounts of organic matter and have a low soil quality and fertility. Accordingly, quite a vast number of nations in Africa already face semi-arid conditions that make agricultural farming very challenging. While soil erosion causes loss of $1 \mathrm{~kg}$ of phosphorus per hectare yearly, the incidence of desertification reduces soil for crop production which in turn breeds food scarcity that often engulfs at risk areas in certain communities of the upper Western African region. Current deforestation trends tend to exacerbate the issue of low soil quality as well. As a result, the per-hectare yields for most crops in the region which stands among the lowest in the world, has been increasing by an average of $42 \%$ since 1980-2005. Climate change, which is caused by carbon emissions into the atmosphere, results in an average increase in global temperatures. This temperature increase has severe implications for farming. The repeated exposures of agricultural space to changing climate change parameters all these years is having notable impacts on production and will increasingly pose severe threats to food security in West Africa. Considering that climate change is expected to reduce areas suitable for agriculture and the length of the growing season, and in many cases impair agricultural efficiency. Flooding in several ECOWAS states has led to drops in production in certain areas with notable constraints on food security $[59,66]$.

\subsection{Efforts towards Mitigation}

The general efforts revolve around many accomplishments to promote food security among countries in the region. Over the years, enough stride has been particularly made in West Africa towards a $63 \%$ reduction of the proportion of people threatened by hunger. Compared to other sub-regions, West Africa has made significant progress, having reduced the number of undernourished people by almost 13 million from 1990-1992 and 2014-2016. With the importance attached to food access among the authorities, 
West Africa has developed several initiatives in support of food security through cooperation between the three main regional Intergovernmental Organizations and with support from partners and Non-State Actors and others. As part of the schemes, the Zero Hunger Initiative for West Africa in line with the UN Zero Hunger Challenge, proclaimed that hunger can be eliminated in our lifetimes. The sub-region is now implementing the initiative to actualize the 2025 Vision on Accelerated African Agricultural Growth and Transformation. Also, the US Government Feed the Future Initiative supports the Comprehensive Africa Agriculture Development Program (CAADP) under the 2014 Malabo Declaration. This aims to sustain the annual agricultural sector GDP growth rate of $6 \%$ among all member states till $2025[3,5]$.

The fact that West Africa is now better equipped has enabled it to make the required progress towards the prevention of food disasters than any other region in Africa. Since the 1980s, the mechanisms for information-sharing and coordinated decision-making have been set up. To that effect, the Food Crisis Prevention Network (RPCA) was created in 1984. The network, which includes West Africa's main food security actors, closely monitors the food and nutrition situation and identifies vulnerable households and areas that require assistance. In addition, during the last three decades, West African regional organizations such the Economic Community of West African States (ECOWAS), the West African Economic and Monetary Union (WAEMU), and the Permanent Interstate Committee for Drought Control in the Sahel (CILLS) have invested extensively in building regional institutions, and human capacities for agricultural development in the sub-region $[3,10]$.

\section{Discussion}

Fundamentally, this study has assessed the growing incidents of food security within 10 countries in the Sub Sahara African zone of West Africa from Senegal, Mali, Niger to Nigeria, Ghana and others using mix scale tools of descriptive statistics and GIS. The enquiry delved on the core problems with coverage of the study area under material and methods and environmental analysis. The research also identified the factors shaping food insecurity trends in the countries and the impacts on the ecosystem as well as the efforts. Aside from the enormity of challenges inherent in the area including the threats of nutritional deficiency, the overdependence on food imports by West Africa, the recurrent nature of famine, the lack of effective policy to spur regional flow of farms goods to needy areas and markets. The dominance of Nigeria in total output and other food security indicators in the region stood out deservedly.

Overall, the results revealed increasing pace of production, surge in area of cropland under cultivation over the years for grains and cereals as well as activities involving exports and imports from 1990-2017 and some inherent constraints built on insecurity in West Africa. This is evident with variations in output, food availability and supply and area harvested, food gaps, and exposures to undernourishment. Consequently, the factors and the effects of food insecurity left in their wake notable problems in the farm producing areas of the region with the conversion of large tracts of arable lands to urban development amidst the threats of extreme climatic events. These problems are compounded further by other limiting elements like ineffective policy, high prices, and lack of credits. The impacts of food insecurity in such settings consist of riots, social unrests, hunger and famine just to mention a few.

To buttress the spatial dispersion of the trends, GIS mapping points to a gradual spreading of food security predictors with firm concentration on the areas at risk and the threats of malnutrition and vitamin deficiency evident across different countries in West Africa. Considering the dangers posed by inaction in mitigating the threats of food crisis, the benefits of the research not only stands out, but it provides a pathway towards the attainment of continual security in food access and output in the West African region. To remedy the challenges identified in the enquiry, the paper offered suggestions ranging from the need for monitoring, design of a regional food information system to the building of storage devices. See Table 9 in the Appendix for a brief summary of the recommendations.

\section{Conclusions}

This research assessed the food security situation in West Africa with many revealing findings listed as follows. a) food production on the rise; b) insecurity evident; c) impacts felt across the region; d) mix scale model effective; e) changing food security triggered by many factors.

The enquiry indicated the growing patterns of farm production occurring over a vast area of crop and agricultural land spread across multiplicity of countries of the West African region. Considering the type of challenges evident in the past, the significance of food security indices and their surge in the study area between 1990 through 2012 from production to import remained quite heartening. The importance of sustained activities in the sector in some periods as catalyst for productivity did stand out, even though food insecurity has not been fully contained among the countries. While the surge in output can be seen from the uptick in the key indices from total grain production to area harvested. From 1990-2012, food production, food availability, supply and land area harvested increased notably. In a region where much of the food produced comes from Nigeria, the trends in that country should not be overlooked in the food security debate. The spate of transactions from these operations to some degree reinforce the increasing volume of activities in the larger farm sector that is driving access and supply in the distribution of merchandises in the market place. Considering the state of 
farm productivity in West Africa, opening and closing info on farm output as shown in this study, reaffirm the significance of the annual showcase of food production index of the study area. Being in an area of the world known for its swats of unused arable farm land and renewable fresh water availability, stressing food security indicators in the policy domain remains a major upside that is necessary for new partnerships and future ventures in the sector.

An important outcome that emerged through this study, which stands as a substantial research contribution, comprises of information highpoints showing the widespread level of undernourished persons as indicated from the different agricultural production indicators in the West African region. The incidence of food insecurity in the study area seems characterized by the proportion and number of underfed and undernourished individuals. In that way, the evidence of food insecurity based on the share of malnourished individuals in overall populace stood firm in Benin, Burkina Faso, Liberia and Chad, Niger, Senegal, and Togo from 1990 to 2016. This is different compared to the nations where the proportions were in single values. During these periods, at double digit average levels, malnutrition cases in both Chad and Liberia surpassed those of the other nations. With the food productivity, and security in the agricultural structure, the bedrock of most polices shaping plans among nations, displaying the extent of malnutrition as a measure of insecurity will inform the capacity of the farm industry, regulators and growers in strengthening production capacities while meeting the needs of a growing number of underfed citizens. Understanding of these trends remains vital in augmenting self-sufficiency in food production in a region with vast potentials but still rattled by insecurity. Knowledge of such challenges in the daily supply chain can move food insecurity further into the arena of public policy and improve the ability to track deficits, output levels and efficiency in line with the region's agenda in meeting the needs of citizens in $21^{\text {st }}$ century.

Another vital revelation that appeared from the analysis stems from the mounting impacts of food insecurity on communities in the study area based on the emergent negative socio-economic and health foot prints over the years. Although the effects of food insecurity in the West African region are manifested through the scales of nascent poverty, social unrest, famine and malnutrition ravaging many areas. Because of the associated stress, per-hectare yields for various produces remain at the bottom in the globe. Accordingly, in the West African Sahel where many have endured harsh and recurrent forms of food stress over the years. Recovery from the last one in 2010 was much harder due to the severe drought that impeded food security for millions of citizens. The emergency stems from irregular precipitation that resulted in low yield, among the nations of Niger, Chad, Mauritania, Mali, and Burkina Faso. Whereas occasional spill overs from the fight in northern Mali forced many individuals out of their localities, such uncertainties pushed people into food stressed areas. For that, tens of millions of West Africans are malnourished, and others encounter food disasters and the impacts of insecurity. Even if the effects of food insecurity transcend different areas, they seem to be concentrated in the arid northern parts of the study area. Seeing the various stressors driving the unwanted emergencies. Pinpointing the scale of vitamin deficiency and the millions of citizens threatened by it and the unrests not only accords them careful consideration in research and management, but it puts future efforts towards food security on a much firmer path than ever.

Considering its relevance, the mix model of GIS and descriptive remained efficient in the execution of the enquiry in several ways. For its part, GIS was quite instrumental in visualizing the nature of changing trends in food security indicators, without such a temporal-spatial framework, decision makers run the risk of prescribing policy change using defective plans at the expense of efficient management, higher yield, and productivity in the region. From the investigative use of GIS in tracking the evolution of food security indicators and their patterns over the region. GIS mapping points to a gradual spreading of food security indicators with firm concentration across different countries. Scrutinizing the dispersion of food security predictors from vitamin A deficiency to changing climatic parameters. This model ushered in a path towards self-sufficiency through greater outputs in farm operations vital for the citizens of West Africa. The effective use of the techniques of GIS and descriptive statistics within a mix scale orientation in this study, thus, shows that the paper provided a valuable methodology for assessing food security trends, potentials and changes in a vast area. Through the application of the mix scale approach, the study results clearly indicate changes in the form of gains and declines in farm variables. The development of these techniques also showcased the feasibility of the methodology at the national and regional scale. Their exploitation in the research, therefore, contributes to our knowledge of food security assessment and potentials of the agricultural sector.

Just as shown in the results, efforts were being made to determine the factors responsible for the changing food security predictors in the West Africa. To locate the food security challenges, including stressors, the enquiry drew from a host of socio-economic, environmental and physical elements in the agricultural structure. The identification of the factors is not only timely, but also a major step in indicating the dangers of food insecurity in farm producing areas of West Africa. Knowing the risks of inclement climate events, there are opportunities for regulators in crafting effective responses for monitoring food emergencies in the areas at risk. Since the factors associated with food insecurity in the study area were not estimated previously. Their roles should be considered by land conservationists. Surely, managers will have enormous chance to appraise the characteristics of the risks by assessing their impacts. The 
fact that these factors unleashed many constraints, makes the analysis herein essential in food security assessments.

From what emerged in the study, policy makers and planners in West Africa will be pressured in the years ahead to seek quick responses to many pressing questions that are relevant to self-sufficiency, productivity and unimpeded surpluses in food. The questions consist of which additional issues are possibly to emerge from agricultural productivity? What new elements can shape the regional distribution of farm produce? In what ways will farm output be impacted by emergent technologies? How will local and global policies influence food security? Drawing from the framing of these questions, countless opportunities exists in each of them for scholarship and practice to reaffirm the focus on food security in West Africa.

\section{Appendix}

\subsection{Recommendations}

Table 9. Suggestions for Future Lines of Actions

\begin{tabular}{|c|c|}
\hline 1 & $\begin{array}{l}\text { Decision makers must start monitoring the pressures on land } \\
\text { zoned for agriculture in order to stop the conversions of arable } \\
\text { farmland to competing uses. }\end{array}$ \\
\hline 2 & $\begin{array}{l}\text { Embrace the use of remote sensing technology and image } \\
\text { analysis based on satellites to track the degradation of food } \\
\text { producing farmland }\end{array}$ \\
\hline 3 & $\begin{array}{l}\text { Favorable line of credits and the right subsidy schemes should } \\
\text { be put in place and extended to sustain West African farmers } \\
\text { and regular supply }\end{array}$ \\
\hline 4 & $\begin{array}{l}\text { The virtues of land ethics built on conservation and efficiency } \\
\text { on the part of land owners and farmers with the help of } \\
\text { agricultural extension workers should be considered with a } \\
\text { blend of mechanized farming integrated with digital tech. }\end{array}$ \\
\hline 5 & $\begin{array}{l}\text { Support the regular assessment of agricultural trends by } \\
\text { monitoring food security predictors including pricing across the } \\
\text { countries in the region. }\end{array}$ \\
\hline 6 & $\begin{array}{l}\text { Encourage the design of an interactive regional food } \\
\text { information system and a digital food atlas with periodic data } \\
\text { on ecologic-economic and social and bio-geoclimatic } \\
\text { components of farming. }\end{array}$ \\
\hline 7 & $\begin{array}{l}\text { Ensure the design of better storage facilities to hold perishable } \\
\text { food items from one season to another for distribution and } \\
\text { planting. }\end{array}$ \\
\hline 8 & $\begin{array}{l}\text { Improve the existing polices with some degree of efficiency by } \\
\text { eliminating trans-border barriers to ensure the free movement } \\
\text { of farm products in a way that eradicates price volatility and } \\
\text { poor transportation infrastructure decay limiting farm supply }\end{array}$ \\
\hline 9 & $\begin{array}{l}\text { Continue regular use of GIS and advanced airborne warning } \\
\text { systems to track the threats of climatic variability to food } \\
\text { security }\end{array}$ \\
\hline 10 & $\begin{array}{l}\text { Embark on periodic public education with an awareness } \\
\text { campaign mounted on the increasing dangers of climate stress } \\
\text { on agricultural productivity in West Africa }\end{array}$ \\
\hline 11 & $\begin{array}{l}\text { Adopt precision farming techniques to aid farmers in } \\
\text { identifying the appropriate spots for planting and allocating } \\
\text { farm resources during the farming season to boost food security } \\
\text { monitoring. }\end{array}$ \\
\hline
\end{tabular}

\section{Acronym}

\begin{tabular}{|c|c|}
\hline Acronym & Meanings \\
\hline PQGE MT & Production Quantity (Grain Equiv. 1000 MT) \\
\hline FAPC- & Food Availability Per capitakg/cap/yr \\
\hline FSGE & Food Supply Grain Equiv. 1000 MT \\
\hline AH1000 ha & Area Harvested 1000 Ha \\
\hline IQ MT & Import Quantity1000 MT \\
\hline EQMT & Export Quantity1000 MT \\
\hline IVM\$mt & Import Unit Value US\$ / MT \\
\hline Tot & Total \\
\hline GDP & Gross Domestic Product \\
\hline Nat & Nations \\
\hline Be & Burkina Faso \\
\hline BFa & Ivory Coast \\
\hline Iv C & Ghana \\
\hline Gha & Liberia \\
\hline Libe & Niger \\
\hline Nige & Nigeria \\
\hline Niga & Senegal \\
\hline Sene & \\
\hline & \\
\hline
\end{tabular}

\section{REFERENCES}

[1] World Bank. (2015 July). Improving Food Security in West Africa: Removing Obstacles to Regional Trade Markets. Washington, DC: The World Bank Group.

[2] Byerlee, D. (2013 January). Growing Africa; Unlocking the Potential of Agribusiness. Washington, DC: The World Bank Group.

[3] United States Agency For International Development (USAID). Agriculture and Food Security. Retrieved May $6^{\text {th }}$ 2018 From https://www.usaid.gov/west-africa-regional/agric ulture-and-food-security.

[4] United States Department of Agriculture (USDA). (2017). Country Historical Data for West Africa 1990-2014. Washington, DC: USDA Economic Research Service.

[5] Merem, E.C. (2018). The Analysis of Food Security Trends In The West African Region. Proceedings of The Association of Social and Behavioral Scientists (ASBS), Conference. Nashville, Tennessee: March 2018.

[6] Merem, E.C. (2018, February). Analyzing the Tragedy of Illegal Fishing By Foreign Vessels on the West African Coastal Region. Proceedings of the 26th Joint Conference of National Association of African American Studies (NAAAS), Dallas, Texas: February 2018.

[7] Hedden, S. (2016). Ending Hunger in Africa: The Elimination of Hunger and Food Insecurity on the African Continent by 2025: Conditions for Success. Denver, CO: Pardee Center for International Futures, University of Denver.

[8] The Economist Intelligence Unit (EIU). (2018). Global Food Security Index. Building Resilience in the Face of Rising Food-Security Risks. The Economist. 1-47. 
[9] Amuwa, S. (2015 January). Boko Haram and Food Security in Nigeria. Retrieved May $6^{\text {th }} 2018$ From. https://economicc onfidential.com/features/boko-haram-and-food-security-in-ni geria/.

[10] FAO (2015). Regional Overview of Food Insecurity in Africa; African Food Security Prospects Brighter Than Ever. Accra, Ghana: Food and Agriculture Organization.

[11] Saheed, M. (2017 January). The Challenges of Food Security in Nigeria. Open Access Library Journal. 4:12 :1-22.

[12] Metu, A. (2016). Achieving Sustainable Food Security in Nigeria: Challenges and Way Forward. Proceedings of the 3rd International Conference on African Development Issues.

[13] Honfoga, B.G. (2003). Food Consumption Patterns in Central West Africa, 1961 to 2000, and Challenges To Combating Malnutrition. Food and Nutrition Bulletin. 24:2:167-182.

[14] FAO. (2010). The State of Food Insecurity in the World-Addressing Food Insecurity in Protracted Crises Rome: Italy. Food and Agriculture Organization of the United States.

[15] USAID. (1992). Policy Determination: Definition of Food Security. Retrieved May $5^{\text {th }} 2018$ From www.usaid.gov/poli cy/ads/200/pd19.pdf.

[16] FAO. (2009). Declaration of the World Summit on Food Security. Rome, Italy: FAO.

[17] FAO. (2017). The State of Food Security and Nutrition In the World 2017. Building Resilience for Peace and Food security. Rome, Italy: FAO.

[18] USDA. (2014). West Africa Rice Annual Senegal Grain Report. Washington, DC: USDA Foreign Agricultural Service, Global Agricultural Information Network.

[19] FAO. (2008). An Introduction to the Basic Concepts of Food Security. In Food Security Information for Action: Practical Guides. Rome, Italy: EC-FAO Food Security Programme.

[20] FAO. (1996). Rome Declaration on World Food Security and World Food Summit Plan of Action. Proceedings of the World Food Summit. Rome: Italy. November 1996.

[21] Maxwell, S. (1996). Food Security: A Post-Modern Perspective. Food Policy. 21:2: 155-170.

[22] Maxwell, S. (1992). Household Food Security; A Conceptual Review. Rome: Italy. UNICEF and IFAD.

[23] World Bank. (1986). Poverty and Hunger: Issues and Options for Food Security in Developing Countries. Washington, DC: World Bank.

[24] Aliber, M. (2009). Exploring Statistics South Africa's National Household Surveys As Sources of Information About Household-Level Food Security. Agrekon. 48:4.

[25] Aliber, M. (2009). Should Subsistence Agriculture Be Supported as a Strategy to Address Rural Food Insecurity? Agrekon. 48:4.

[26] Altman, T.G. (2009). Household Food Security Status in South Africa. Agrekon. 48:4.

[27] Du Toit, D.C. (March 2011). Food Security. Republic of South Africa: SA. Department of Agriculture and Fisheries.
[28] Ahungwa, GT. (2014). Food Security Challenges in Nigeria: A Paradox of Rising Domestic Food Production and Food Import. International Letters of Natural Sciences Online. 18: $38-46$.

[29] Akande S.O. (1998). Public Policy in Nigeria Agriculture In Institutional Reforms for Agriculture Development. Triumph Books Publishers.

[30] Adeagbo, M.O. (2012). Curbing the Menace of Food Insecurity in Nigeria's Democratic Setting. International Journal of Economic Development Research and Investment, 101-109.

[31] Ojo, E.O. (2012). Food Security in Nigeria: An Overview. European Journal of Sustainable Development. 1:22:199-222.

[32] Ogen, O. (2003). Patterns of Economic Growth and Development in Nigeria Since 1960. Lagos, Nigeria: First Academic Publishers.

[33] Lawal. A.A. (1997). The Economy and The State from the Pre-Colonial Times to The Present. Ibadan: Nigeria: Davidson.

[34] Babatunde. R.O. (2012). The Role of Nigerian Agriculture in West African Food Security. Garki Abuja, Nigeria: International Food Policy Research Institute.

[35] Ghana Ministry of Food and Agriculture. (2017). Planning Food and Jobs: Strategic Plan For Implementation (2017-2020). Accra, Ghana: Ghana Ministry of Food and Agriculture.

[36] FAO. (2015). Agricultural Growth in West Africa: Market and Policy Drivers. Rome, Italy: Food and Agricultural Organization.

[37] ECOWAS (Economic Community of West African States). (2005). Adopting An Agricultural Policy For the Economic Community of West African States. Accra, Ghana: ECOWAS.

[38] ECOWAS. (2006 July). Joint ECOWAS/UEMOA Meeting Agrees on Roadmap For Planned Introduction of Common External Tariff. Abuja, Nigeria: ECOWAS.

[39] Oya, C. (2006). From State Dirigisme to Liberalization In Senegal: Four Decades of Agricultural Policy Shifts and Continuities. European Journal of Development Research. 18 2:203-34

[40] AfDB. (2012 July). Highlights of The Food Security Situation in Africa. Quarterly Bulletin Chief Economist Complex. 3.

[41] UK Department for International Development. (2012). West Africa: Food Aid For Half a Million People In the Sahel. Retrieved May $5^{\text {th }} 2018$ From https://www.gov.uk/governm ent/news/west-africa-food-aid-for-half-a-million-people-in-t he-sahel.

[42] FAO. (2014 July/August). Food Security and Humanitarian Implications in West Africa and the Sahel. Dakar, Senegal: WFP Regional Bureau. 58.

[43] Development and Peace. (2012 May). Development and Peace Commits \$5 Million For Food Aid in West Africa. Montreal, Quebec: Canada.

[44] UN Office for the Coordination of Humanitarian Affairs. (2018). Sahel Overview of Humanitarian Needs and 
Requirements. Retrieved $6^{\text {th }}$ May 2018 Fromhttps://reliefwe b.int/sites/reliefweb.int/files/resources/Sahel\%20HNRO\%20 2018.pdf.

[45] Organization for Economic Co-operation and Development. (OECD 2018). Stats of the Week: Food Security in West Africa. Proceedings of the Sahel and West Africa Expo. Milan: Italy. October 26-30, 2015.

[46] Idiku, F.O. (2016). Food Insecurity Challenges and Sustainable Agricultural Development in Nigeria. Retrieved May $5^{\text {th }} 2018$ fromhttp://www.ssrn.com/link/OIDA-int-Jour nalSustainable-Dev.html.

[47] FAO. (2011). Global Food Losses and Waste: Extent, Causes and Prevention. Rome: Italy. FAO International Congress.

[48] Genesio, L. (2011 February). Early Warning Systems For Food Security in West Africa: Evolution, Achievements and Challenges. Atmospheric Science Letters.12: 142-148.

[49] Ojukwu, C. (2014 November). Realizing West Africa's True Agricultural Potential. Abidjan: Ivory Coast. African Development Bank. Agriculture and Agro-Industry Department.

[50] Merem, E.C. (2017a). Assessing Ecosystem Liabilities of Oil and gas activities in southern Nigeria. Public Health Research. $7: 1: 3-26$.

[51] Merem, E.C. (2012). Tropical landscape change and the role of agroforestry in southern Nigeria. British Journal of the Environment and Climate Change. 2:3:285-319.

[52] Merem, E.C. (2019 February). The Analysis of Cocoa Farming Activities in the West African Region. 28th Joint Conference of National Association of African American Studies (NAAAS). Dallas, TX.

[53] Population Reference Bureau. (2018). Population and Food Security: Africa's Challenge (Part 1)/ Washington: DC.

[54] Merem, E.C. (2006). GIS and remote sensing applications in the assessment of change within a coastal environment in the Niger delta region of Nigeria. International Journal of Environmental Health and Public Health. 3:1: 98-106.

[55] Merem, E.C. (2008). Using geospatial information technology in natural resources management: The Case of Urban Land Management in West Africa. Sensors. 8: 607-619.
[56] Merem, E.C. (2007). Using GIS and Remote Sensing in the Analysis of Ecosystem Decline along the River Niger Basin: The case of Mali and Niger. International Journal of Environmental Health and Public Health. 4:2: 278-289.

[57] Worldometers. (2018). Population World/Africa Population Sections. Retrieved $5^{\text {th }}$ June 2018 From http://www.worldo meters.info/world-population/.

[58] Merem, E.C. (2018). Appraising Variations In Climate Change Parameters Along The Lower West African Region. Journal of Safety Engineering. 7:1:1-19.

[59] Christoph, S. (2013 September). Home Food and Water Africa's Challenge in the $21^{\text {st }}$ Century-Food Security. Retried $5^{\text {th }}$ June 2018 From https://www.resilience.org/stories/201309-26/africa-s-challenge-in-the-21st-century-food-security.

[60] Sasson, A. (2012 April). Food security for Africa: An Urgent Global Challenge. Agriculture \& Food Security.1:2.

[61] Fausold, E. (2018 February). Drought in West Africa Threatens Food Security. Washington, DC: World watch Institute.

[62] Flores, M. (2004 January). Conflicts, Rural Development and Food Security in West Africa. Rome, Italy: FAO ESA Working Paper No. 04-02FAO, Agricultural and Development Economic Division. 1-23.

[63] Merem, E.C. (2017a). Analyzing Rice Production Issues in Niger State Area of Nigeria's Middle Belt. Food and Public Health. 7:1:7-22.

[64] Merem, E.C. (2017 September b). Assessing Variations in Climate Change Parameters In The Lower West African Region. Proceedings of the 14th International Symposium on the Recent Advances in Environmental Health. Jackson, MS.

[65] Merem, E.C. (2019 February). Assessing Organic Farming Trends in the West Region of the United States. Proceedings of the Mississippi Political Science Conference, Hattiesburg, MS.

[66] Parry, M.L. (2007). Climate Change Impacts, Adaptation and Vulnerability: Contribution of Working Group II to the Fourth Assessment Report of the IPCC. New York: Cambridge University Press. 